\title{
The Application Research of "The Kite" Law in Chinese Universities Logistics Reform
}

\author{
Yajun Yin \\ Qidong Campus Management Committee of Nantong University, Nantong, China \\ Email: yyy@ntu.edu.cn
}

Received 16 June 2014; revised 20 July 2014; accepted 28 July 2014

Copyright () 2014 by author and Scientific Research Publishing Inc.

This work is licensed under the Creative Commons Attribution International License (CC BY). http://creativecommons.org/licenses/by/4.0/

(c) (i) Open Access

\begin{abstract}
"The Kite Management Philosophy" tells us: Before making change, an organization should fully understand the surrounding environment, prepare related factors and develop a suitable system. After the conditions are ripe, it must boldly implement the organizational goals and be good at controlling. The current biggest problem of obsessing and obstacle of the Chinese universities logistics reform is not properly handling the relationship between logistics public welfare and marketability. The dependence relationship of the two aspects is like a flying kite-more public welfare means taking back and more marketability means flying off. Managers should follow "The Kite Management Philosophy", timely release and recycle the cord according to the actual situation. They should dare to reform, be good at controlling and have the courage to innovate.
\end{abstract}

\section{Keywords}

Modern University System, Chinese Universities Logistics Reform, The Kite Management Philosophy

\section{The Connotation of "The Kite" Law}

Kite is a product, which is heavier than air and can float on the air with the help of wind. It is one of the traditional folk games in China. Flying a kite goes through three processes: releasing, handling and recycling. Every link has points to pay attention to: Firstly, in the link of releasing, the caster should make clear of the direction of the wind, fly the kite in the headwind way and hurriedly rise at the same time when the wind comes. Keep running and releasing. The take-off process is not successful until the kite reaches to a certain height. Secondly, in the link of handling, the kite in the sky should maintain relative balance. It's the most ideal state of kite at this moment, but we must adjust to the unstable situation of the wind direction and wind power. Lastly, recycling the kite is relatively easy, as long as avoiding recycling the cord too urgently; otherwise it will damage the kite. As 
is well-known, there are two necessary conditions in flying a kite. The first is to be in windy weather, so the kite can fly; the second is to have cord traction, the kite can be controlled. Flying a kite looks like simple, but making a kite meanwhile achieving freely state is very difficult.

Thus we can conclude from "The Kite" Law: The success of flying a kite depends on four factors - the power of the wind, the quality of the kite, the length of the cord and the skills of flying off. It's like the internal structure of an organization: The power of the wind is like the organization's environment; the kite refers to the employees of the organization; the cord refers to the various strategy and organization systems; the skills refer to the various management measures. If an organization wants to achieve certain management objectives, before reforming, it must fully understand the surrounding environment, prepare related factors and work out suitable systems. After the conditions are ripe, it must boldly implement the organization goals. In the process of implementation, it must be good at controlling and achieve elastic degree of straining and releasing freely.

\section{The Current Situation of Chinese Universities Logistics Reform}

At present Chinese universities are establishing a modern university system, which is the fundamental system of a national or regional higher education system. China's "National Mid-and-Long Term Education Reform and Development Plan Outline (2010-2020)" points out, "Improve the modern university system of Chinese characteristics and the governance structure"; at the same time explicitly proposes "Promote universities logistics socialization reform". The logistics system reform belongs to school system reform of micro level and it's an important aspect of modern university system construction (Li, 2010). Now the great importance China attaching of Chinese universities logistics reform is like the heavy wind, creating a good external environment for flying kite.

Since the reform and opening up, especially in nearly a decade, constantly promoting Chinese universities logistics socialization reform, China has made remarkable achievements and provided the precious experience for the higher education reform and the modern university system improvement. Meanwhile many new situations and new problems also appear: mechanism is not perfect, as in the real problem involving part of workers status change is difficult to promote; System is not reasonable, the universities logistics management systems dominated by the strong administration, cause the regardless separation between institution and enterprise, hamper the further deepening of the logistics reform; Property right is not clear, the right of the state-owned assets and owned property of logistics are not clear; Management is not scientific, logistics reform does not operate according to the market laws. These problems lead a large number of universities into going back to the original logistics management mode after the logistics socialization reform proceeds for a period. It has an undoubtedly greater deviation comparing with China's vision of the logistics direction of socialization, marketization and enterprization, constantly changing policy environment makes a lot of universities confused.

Management of universities has the duality, education attribute and economic attribute. So the university logistics management also has the duality, the manifestation is public welfare and marketability. Public welfare means in the life service for the teachers and students, not for the purpose of making profits, but the pursuit of public social interests. Marketability means in the life service for the teachers and students, following the rules of market and pursuing reasonable economic benefit or profit at the same time of keeping public welfare. The current foreign universities are all using the market mechanism, implementing enterprise management, so that the school can get rid of a lot of everyday multifarious life burden, improve the teaching efficiency, such as Germany and France. But after the reform of more than a decade in our country's universities, most of the universities logistics don't really achieve the "socialization". Through analysis, we believe that the biggest problem of obsessing and hindering the Chinese universities logistics reform is the deviation in cognition on the relationship between the logistics public welfare and marketability, not properly handling the relationship between each other. This is because since reform, university logistics has been integrated into the socialist market economy, as an economic entity, it must follow the economic laws and pursue certain economic benefits. Like flying a kite, the caster should dare to let it go, take economic benefit as important, rise in the price and adjust to needs, so that this problem will not appear in the logistics reform which will go on very well. But at present most of the universities regard logistics as generally for-profit companies, not only do they not give basic subsidies, but also require unrealistic returns; some universities overemphasize public welfare, both high quality service and maintaining stability, the universities logistics can't rise in price according to the market. This has caused the price lower than the value for a long time, the price less than the value, logistics even has a loss instead of a economic benefit. If things go on like this, universities logistics socialization reform work will get into a critical moment 
of a dilemma.

In the year of 2012 in China “The University Logistics Mid-and-Long Reform and Development Plan Outline” also clearly points out in its guiding ideology: "Follow the education laws and economic laws, handling the relationship between the public welfare and marketization”. At present Chinese university logistics is hovering in the crossroads of deepening reform. Dialectic analysis of the mutual relation between the public welfare and marketization of university logistics is an important premise of promoting the success of the logistics socialization reform (Chen, 2009). In fact, the dependence relationship of public welfare and marketization like a flying kite. More public welfare means taking back and more marketability means flying off. Like a kite flying in the midair, the caster is afraid to release and also don't want to recycle. At this time if the caster is less determined, or grasp the bad method, the kite will not fly high and will fall down at any time. So in the practical work we should follow “The Kite” Law and correctly handle the problem of releasing and recycling. It has great significance for further deepening the logistical socialization reform.

\section{Inspiration for Chinese University Logistics Reform from "The Kite" Law}

\subsection{Dare to Reform}

Chinese universities logistics reform has made remarkable achievements for years, but still in primary stage. At the beginning of the logistics reform, it should be on the premise of speeding up reforms and doing a good job. As the American management scientist Stephen P. Robbins says, "Successful organizations will be the ones that can change in response to the competition” (Robbins, 2004). It's like a kite about to fly, when all conditions are ripe, the caster should actively release the cord to let the kite flies with the wind. If we want to release, and also want to grab, the kite is very difficult to fly in the sky.

After universities logistics go into the operation of marketization mode, the first thing is to face the reality, the cruel and fierce competition market. It must make reasonable and effective use of existing resources and conditions, realizing the optimization of economic benefits in the business (Ma, 2013). This makes us have to change views, increase the intensity of reform and abandon some restricting factors in the market-oriented process. Because only attaching importance to economic benefits firstly, university logistics of getting into the socialization can operate and develop with constantly adapting to the rules of market economy, have certain accumulation, thus university logistics management can operate efficiently.

At present Chinese university logistics reform is also in confusion, there are some different voices in the process of reform. "Marketization reform” raises some people's question, the impetus of reform becomes weak. Schools and logistics management department want both economic benefit and social benefit, this itself is very contradictory, undoubtedly set up an invisible shackles in the process of reform. When it comes to the relationship between the public welfare and marketability, most experts and scholars all also agree to both opposition and unification between them. That is to say, in the process of logistics reform we should not only adhere to the public welfare, and consider economic benefit, it is difficult to deal with that in reality. If we blindly give priority to the public welfare, reform will have no incentive and can't go forward; If we stick to both public welfare and economic benefits, the reform will hesitate to move forward; If we adhere to give priority to the economic benefit according to market rules, we will be bound to be questioned and thought that logistics reform deviate from the direction. So Chinese universities should seize the current strong time of constructing the modern university system, further emancipate the mind and change ideas. Let the kite of reform soar. As the chief designer of China's reform and opening up, Mr. Deng Xiaoping putted forward at the beginning of reform and opening up, "Whether a white cat or black cat, which can catch mice is a good cat." Much reform experience shows that if at the beginning of the reform we are timid, reform is doomed to fail. Without the bold transformation of the concept, reform cannot be successful.

\subsection{Good at Controlling}

Currently there are some universities logistics deviating from the direction in the reform, emphasizing the marketability blindly, pursuing too much economic benefits and forgetting that the public welfare is the essential attribute of education, thus it causes the people's question to reform. This kind of one-sided emphasis on the economic benefits of logistics management, ignoring its public welfare, deviates from the aim of the university logistics work, damages the fundamental interests of the general teachers and students. It requires that we must be good at controlling in logistics reform. Like a soaring kite, timely adjusts to the case of special situation. If 
we let it fly freely till total cord finishes, the result will be out of control.

Chinese universities logistics reform should adapt to the transformation mechanism of socialist market economy and operate according to the law of value, of course have economic accounting and pursue economic benefits. Accounting must pay attention to economic benefits, but can’t one-sided pursue economic efficiency. Universities is the place for cultivate talents, must also strive for the social benefits. In the process of the establishment of the modern university system, on the premise of guaranteeing public welfare, first of all the universities logistics must boldly reform and pay attention to certain economic benefits or profits. However, the premise of increasing economic efficiency is to serve better for school teaching, scientific research and the teachers, students and other staffs, the purpose is to improve the survival and development of university logistics service enterprises. As the American scholars, James Collins and Jerry I. Porras co-authored "Built to Last" says, "Profits is the prerequisite of survival, and it is the measure to achieve more important goal, but for many forward-looking companies, profit is not the purpose, it is like oxygen, food, water and blood, which our bodies need. These things are not the purpose of life, but without them, there would be no life” (Collins \& Porras, 2002). Making clear the relationship between each other, we can target and control freely in the daily management. So in the work we should make good deal with the relationship of complementation and communion between the two aspects, pay attention to the organization's long-term interests and immediate interests and overall interests and partial interests, so that we can better master the public welfare and marketability of the universities logistics, and promote synchronous growth of social benefits and economic benefits of the universities logistics.

In the daily practical work, according to the actual situation, we should be flexible to deal and able to control, achieve the degree of the major and minor, first and last. Just like flying a kite, adjust timely to winds or other special status in high sky, release and recycle cord. Through the reform university logistics has a certain accumulation, which is also a certain economic benefits, then it also enters the reform coordinated phase, at this time we will pay attention to the public welfare that the universities logistics should take on, shift giving priority to the pursuit of economic benefit to the public welfare. That is to say when the kite reaches to a certain extent, according to the direction and the intensity of the wind, pay attention to control the cord, decide to release or recycle the cord in time, if we can find a good balance point between them, kite can continue running smoothly. Logistics managers will return part of the economic benefits to school or teachers, students and staff for greater social benefit, through feeding back to the public welfare. At the same time, good social benefits will promote the improvement of the economic benefits as well, becoming a virtuous cycle, logistics deepening reform can proceed smoothly.

\subsection{Have Courage to Innovate}

Innovation is the inexhaustible force for a country and a nation to stand in the world community, is also the important source for an organization to go forward constantly. Vitality and energy of education enterprise lie in constant reform and innovation. At present university logistics socialization reform has entered the deep waters area, should have courage to innovate and solve the current difficulties through some innovative means and methods. Just like flying a kite, if there is no innovation in the material of the kite and the technology of flying, can't be different from others, so the kite will not fly high, fly far and fly stably.

Currently in the process of reform the schools can be found everywhere, which think little of innovating strategy thinking, scientific management system and operation mechanism and management culture. Some universities logistics haven’t reached a certain condition in terms of scale, quality, mechanism, but they copy the socialized reform from other schools, the result of course would be failure. Each university has its own characteristics, whose logistics development is also not balanced. They should seek the development according to their own actual conditions. If blindly copy, not only will the reform not succeed, but also it will further increase the management costs, becoming the resistance of the development of universities.

In the practical work, the universities should combine their own development situation, in a variety of form, adjust measures to different universities and local conditions, explore new reform thinking. University logistics management items and service items are numerous, according to the different nature of the items. We can determine the emphasis of the pursuit of social benefit and economic benefit and make different treatment in the degree of releasing and recycling. For the service items of directly guaranteeing the universities' activities of teaching and researching, we should give priority to the public welfare; and for the services of being divided into operational items, we should on the management give priority to economic benefit. Taking advantage of available school scale, they can build their own production and supply base, expand external sales in the case of gua- 
ranteeing subsistence, actively participate in market competition and create good economic benefits. They can also break down the barriers among schools by region, implement resource sharing of university logistics, establish university logistics enterprise alliance and further reduce the cost, etc.

\section{Conclusion}

At present, Chinese universities logistics reform just like a kite begins to fly. In the case of completing all conditions, managers need to resolutely release the cord, be good at adjusting when the kite rises to a certain height, note that random strain according to actual situation, adjust measures to local conditions and follow "The Kite" Law. The law has positive significance for Chinese universities logistics reform and management, not only can promote Chinese universities logistics reform, and can effectively grasp the direction of the reform and make the universities logistics reform meet the practical demand of Chinese society. Of course, wanting to truly implement "The Kite" Law in Chinese universities logistics management in the future, we also need more attempt and exploration, in order to form management method of distinct characteristic. This is the important direction of the future research of "The Kite" Law applying in Chinese university logistics reform.

\section{Acknowledgements}

This work was supported by the 12th Five-Year Planning Project of Jiangsu Education Science (No. C-c/ 2013/01/052). And it was supported by the philosophy and social science fund project from Jiangsu Province Office of Education: "Research on Improving the Effectiveness of Ideological and Political Education by the Computer Persuasion Theory” (No. 2011SJB880111).

\section{References}

Chen, D. X. (2009). The Countermeasure Research of Balancing Contradictions of Public Welfare and Marketability of the Universities Logistics. Manager Journal, 9, 297.

Collins, J. C., \& Porras, J. I. (2002). Built to Last: Successful Habits of Visionary Companies (Translated by Ru Zhen). Beijing: CITIC Press.

Li, J. X. (2010). The University Logistics Reform of the Construction of Modern University System. Beijing Education, 12, $32-33$

Ma, W. D. (2013). The Value Fusion of Modern University System and Universities Logistics Management. Journal of Huazhong Normal University (Humanities and Social Sciences), 1, 32-33.

Robbins, S. P. (2004). Management (Translated by Jianmin Sun and Yuan Li) (7th ed.). Beijing: China Renmin University Press. 
Scientific Research Publishing (SCIRP) is one of the largest Open Access journal publishers. It is currently publishing more than 200 open access, online, peer-reviewed journals covering a wide range of academic disciplines. SCIRP serves the worldwide academic communities and contributes to the progress and application of science with its publication.

Other selected journals from SCIRP are listed as below. Submit your manuscript to us via either submit@scirp.org or Online Submission Portal.
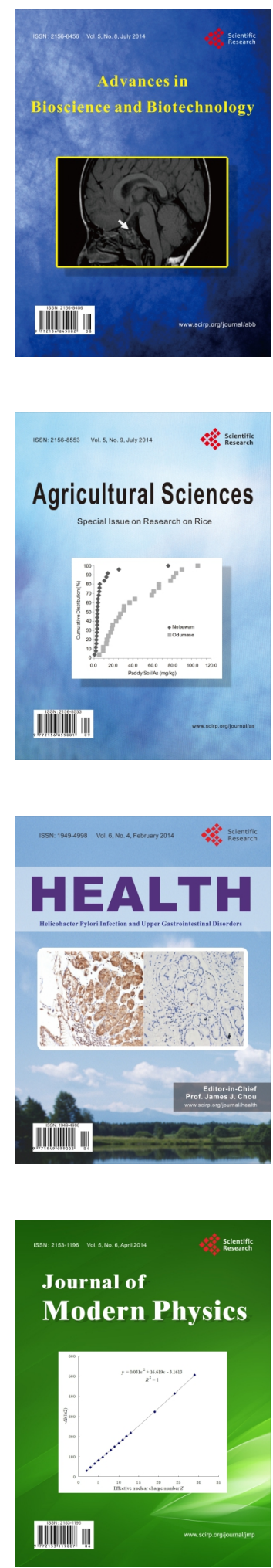
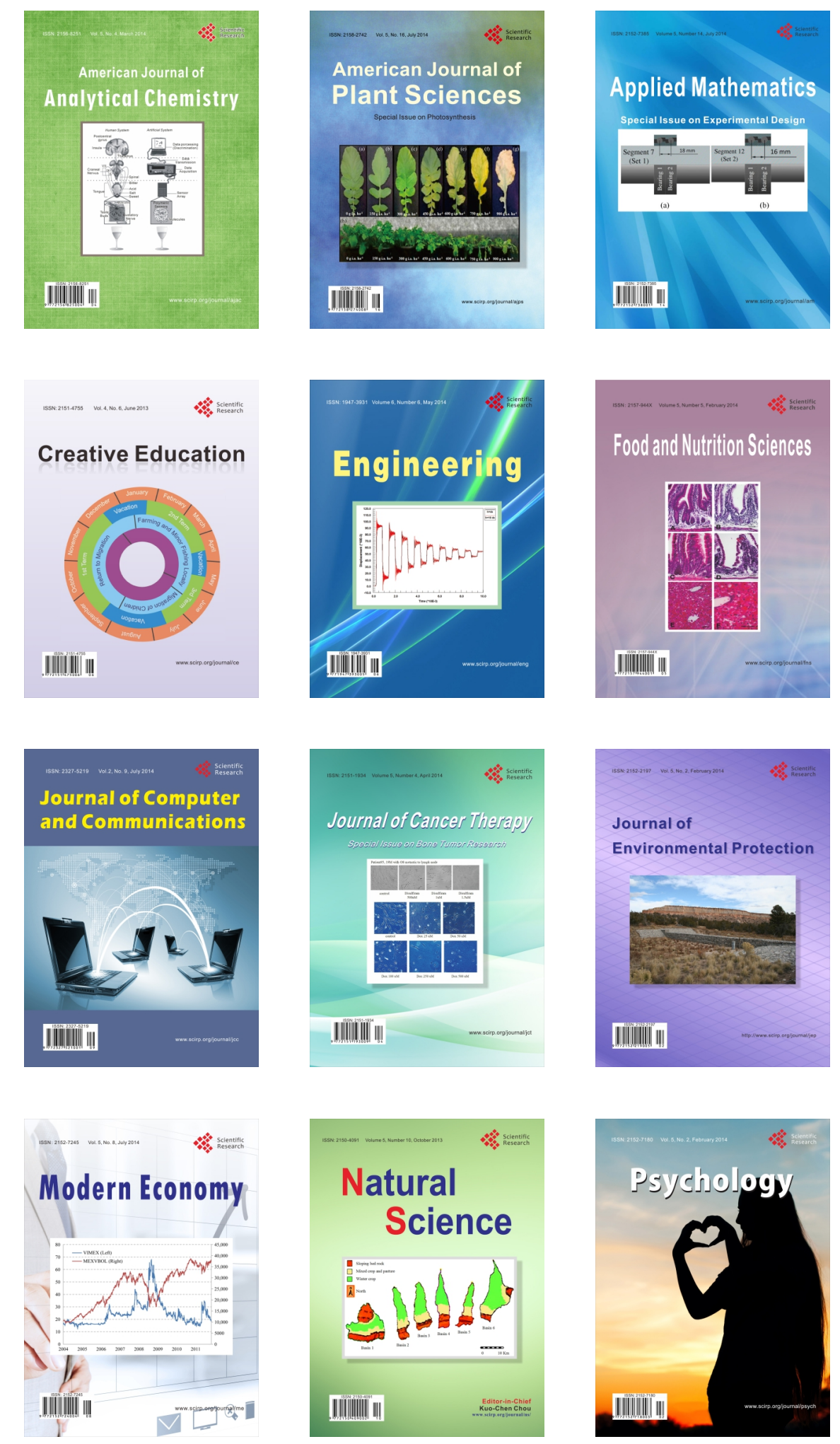